informed through a well-designed integrated network system.

Planning - going from a vision of the future through to policy, establishing the ground rules, then to architecture - providing the strategic technical blueprint, is the essential component for managing telecommunications as a business resource.

Ihis is an eminently readable book. Peter Keen, in straightforward non-technical language, provides guidance on how to harness the power of modern telecommunications to the business and how to plan the strategies for successfully in tegrating new technologies into a competitive plan. Computing in Time is a must for business managers and executives who want to ensure that their companies are not locked out by their own customers or the competition.

\section{Catherine Griffiths}

Apocalypse' 2000: Economic Breakdown and the Suicide of Democracy 1989-2000 by Jay, Peter and Stewart, Micbael. Published by Sidgwick and Jackson, London, 1987. $<12.95$.

IT Futures ... IT Can Work - an Optimistic View of the Long-Term Potential of Information Tecbnology for Britain by NEDO Long-Term Perspectives Group. Published by HMSO, London, 1987. £20.00. 172pp.

Prediction is a dangerous business - it is easily attacked and leaves hostages for the future; even Arthur C. Clarke has made mistakes. The two books reviewed here seek to identify factors which should be addressed now if potential pitfalls are to be avoided in the future.

Apocalypse 2000 looks at the political and economic future up to the end of the twentieth century and comes to depressing conclusions. The European Community sinks into what amounts to Fascism under the banner of 'Europe First'. Like the rise of Hitler it is initially democratic and seeks to eradicate unemployment caused by the allegedly unfair trade practices of non-European countries, although it is less aggressively racist than the Nazis.

The USA also goes to the right by electing a television evangelist of the 'moral majority' but of very limited political capacity.

Growing foreign and especially Japanese import penetration in the USA leads to increasing pressure on domestic firms which results in protectionism. This fails to cut unemployment because the goods cannot be replaced by domestic US firms either in quality or quantity. Japanese marketing efforts are thereafter directed into Europe and the Third World. The consequence of this is to put further pressure on European industry leading ultimately to more protection. The blame for all this is put squarely on President Reagan, for his build-up of defence spending with the consequent budget deficit and the failure to invest in commercial research and development in the USA.

The only comfort, if such it is, is that Japan comes under increasing pressure from the SuperNICs (newly industrialized countries), namely Taiwan, South Korea, Hong Kong and Singapore.

What makes this book disturbing is that nothing new happens here; the historical precedents are all there and the reader is reminded of them. In that sense it is plausible. It is not difficult to identify ways in which it might not happen, in which it could be avoided or in which it could be much worse. The real issues arise from the weaknesses in individual countries, in Western democracy and in the free trade system. The message is to attack unemployment now, before it corrodes the social structures beyond the point at which they can bear the stresses of change.

The presumption appears to be that manufacturing power wins the day and therein lies the advantage of Japan and the Super-NICs. Technology plays an important but decidedly secondary role. Europe should have phased out subsidies to traditional industries and agriculture sooner, encouraged investment in new information-based technologies, and promoted research and development, training and re-training.

IT liutures examines the slightly longer period up to the year 2010 considering the social, economic and technical forces and their relationship with information technology. The approach used is to build scenarios describing the results of a number of possible trends. The view taken is one of technological optimism, rather than determinism.

Those applications of IT which can currently be foreseen hold enormous potential to change society, industry and the lives of individuals. This is through the facility of allowing people to carry out existing activities faster or in new locations and to do completely new activities. Thus people can spend more of their time as they wish.

The criteria used in such selections are broken down, somewhat crudely, into three classes:

1. materialist, where the views held by others are most important;

2. autonomous, where an individual's own views predominate;

3. subsistence.

While all three classes will always be present in society, the balance will determine the direction 